\title{
DIVIDEND PAYOUTS: MAJORITY CONTROL AND RENT EXTRACTION
}

\author{
Seniha BESIM ${ }^{1}$, Cahit ADAOGLU ${ }^{*}$ \\ ${ }^{1}$ Department of Banking and Finance, Faculty of Business and Economics, Eastern Mediterranean \\ University, Famagusta, North Cyprus, via Mersin 10, Turkey \\ ${ }^{2}$ Department of Banking and Finance, Faculty of Business and Economics, Eastern Mediterranean \\ University, Famagusta, North Cyprus, via Mersin 10, Turkey
}

Received 19 January 2018; accepted 15 October 2018

\begin{abstract}
In Eurasia, Turkey has a "crony" capitalist system with majority control and business groups (BGs) in the hands of a few families. These business groups are often organised around a holding company. We analyse the dividend payouts of family controlled Borsa Istanbul companies, which are affiliated to holding and non-holding BGs. We investigate and quantify the effects of several control-enhancing mechanisms (CEMs) on dividend payouts. We use precise quantitative proxies for CEMs to measure the divergence between control and ownership rights. Supporting the rent extraction hypothesis, holding business group companies have lower dividend payouts as the divergence between control and ownership rights widens and the pyramid wedge increases. However, controlling foreign-family coalitions in holding business group companies curb the rent extraction problem by having a positive effect on the dividend payouts. Overall, for family controlled holding BG companies, the effects of company-specific financial control variables on dividend payouts are stronger than the effects of CEMs. For family controlled non-holding BG companies, there is no empirical support for either the rent extraction or the reputation building hypotheses. The company-specific financial control variables are the main determinants of dividend payouts for family controlled non-holding BG companies.
\end{abstract}

Keywords: dividend, control, ownership, holding, foreign, rent extraction, reputation building, substitution, expropriation.

JEL Classification: G32, G34, G35.

\section{Introduction}

In Eastern Europe, countries implemented mass privatization programs during their transition process to a market-based economy, which is commonly regarded as a transition to a "crony" capitalist system. The transition process resulted in majority control of large shareholders (outsiders), company managers and workers (Tvaronavičiene \& Kalašinskaite, 2005;

${ }^{*}$ Corresponding author. E-mail: cahit.adaoglu@emu.edu.tr 
Bennedsen \& Nielsen, 2010). In Eurasia, Turkey experienced a slow transition process to a "crony" capitalist system. The resulting ownership structure is majority control, similar to the ones in Eastern Europe. Individuals with political connections, entrepreneurial expertise and capital were successful in taking over many state companies, which resulted in the formation of diversified business groups in the hands of a few families as majority controllers (Yurtoglu, 2000).

Family control is strikingly higher in Turkey than in other countries, and approximately 79\% of companies traded on the Borsa Istanbul (BIST) are family controlled (Yurtoglu, 2000, 2003). ${ }^{1}$ Moreover, BIST companies are typically affiliated to family controlled BGs, which are typically grouped under the umbrella of a financial holding company serving as an intermediary control entity. This organizational structure is known as a holding BG. There are also family controlled non-holding BGs that do not use a holding company as an intermediary control entity. In both family controlled holding and non-holding BGs, control-enhancing mechanisms are used. In particular, CEMs such as pyramid structure and dual class shares result in divergence between control and ownership (cash flow) rights which enable the families to control a group of companies by injecting less family capital. In such ownership structures, family controlled companies can expropriate minority shareholders, especially in countries that have low investor protection (e.g., Liu \& Magnan, 2011; Pindado, Requejo, \& Torre, 2012).

In the corporate governance literature, the rent extraction hypothesis and the reputation building hypothesis make opposite predictions about the dividend payout. The rent extraction hypothesis predicts that controlling families pay low dividends to keep resources under their control. However, the reputation building hypothesis (i.e., also known as the substitution hypothesis in the literature) predicts that controlling families pay more dividends to build a reputation and to signal that they do not expropriate minority shareholders. When expropriation concerns are not alleviated, company value is discounted and investors ask for greater returns to supply capital (Faccio, Lang, \& Young, 2001).

The purpose of this study is to determine whether there is a difference in the dividend payouts of family controlled holding and non-holding BG companies. Specifically, we examine the dividend payouts of family-controlled companies in both holding and non-holding BGs operating in Turkey, which is classified as a Eurasian emerging market with weak minority shareholder protection settings (World Economic Forum, 2017). Our objective is to empirically explore whether controlling families use dividends for rent extraction or for reputation building by examining the effects of several quantified control-enhancing mechanisms (CEMs) on dividend payouts. Within the frameworks of rent extraction and reputation building hypotheses, we focus on the question of whether holding BG companies behave differently in terms of their dividend payouts than non-holding BG companies.

Following the pioneer studies by Faccio et al. (2001), and La Porta, Lopez-De-Silanes, Shleifer, and Vishny (2000), specifically, we use the control-ownership wedge to measure the likelihood of rent extraction. However, Faccio et al. (2001) stress that "Since the O/C [the ownership-control wedge] ratio might fail to reflect this threat [expropriation] fully, our

\footnotetext{
${ }^{1}$ Family control is $44.29 \%$ in Western Europe (Faccio \& Lang, 2007). In East Asia, it is 38\% (Faccio et al., 2001), while in the US, 33\% of S\&P 500 companies are controlled by families (Anderson \& Reeb, 2003).
} 
regressions are biased toward finding insignificant results" (p. 57). We go one step further and analyse the likelihood of rent extraction by decomposing the ownership control wedge into its components, namely pyramid wedge and dual share wedge. For the decomposition, we benefit from the framework of Villalonga and Amit (2009) that is used for testing the value effects of CEMs for family controlled U.S. companies. This study is the first in the dividend literature in a weak investor protection setting to precisely decompose the control-ownership wedge into a pyramid wedge and a dual share wedge to differentiate their respective effects on dividend payouts. Studies tend to use dummy variables instead of quantifying pyramid and dual share CEMs (e.g., Pindado et al., 2012; Amoako-Adu, Baulkaran, \& Smith, 2014; González, Guzmán, Pombo, \& Trujillo, 2014).

We use panel random effects Tobit estimation to analyse 134 family controlled BG companies traded on the BIST for a period of eight years, 2010-2017. We find that $80 \%$ of nonfinancial BG companies listed on the BIST are controlled by families, and $72 \%$ of these family controlled companies are controlled through holding companies. Focusing on the controlownership wedges, the Tobit estimation results show that for family controlled holding BG companies, the rent extraction hypothesis is empirically supported. Overall, for these companies, the effects of company-specific control variables on dividend payouts are stronger than the effects of CEMs. For family controlled non-holding companies, both the rent extraction and the reputation building hypotheses (i.e., CEMs) fail to explain the dividend payouts, and the company-specific financial control variables are the only determinants.

The rest of the paper is structured as follows. In Section 1, we provide the theoretical background and literature review. Section 2 presents the Turkish business settings and our hypotheses. Section 3 describes the data and the methodology. In Section 4, we present the empirical results and provide robustness results. Finally, we conclude by summarising our findings, and stating research limitations and future directions for research.

\section{Theoretical background and literature review}

In Miller and Modigliani's frictionless world with perfect information, no taxation and no effect on company investments, dividend policy does not affect the market value of companies (Miller \& Modigliani, 1961). However, in the real world of conflicts of interests, taxes and asymmetric information, companies use dividend policy to mitigate these problems. Particularly, in determining the dividend policy, corporate governance plays a vital role. The corporate governance literature typically focuses on two types of agency problems within the framework of agency theory. The first (Agency Problem I) is the classical principal-agent conflict, that is, especially a concern in companies with a dispersed ownership structure (Jensen \& Meckling, 1976). Concentrated control results in a second type of agency cost (Agency Problem II) that results from conflicts of interests between controlling shareholders and minority shareholders.

In the following sections, firstly, we discuss the hypotheses and the literature focusing on the Agency Problem II of agency theory since it is prevalent in markets with weak investor protection settings, such as those in Eurasia and Eastern Europe. Secondly, the other relevant dividend hypotheses and literature are discussed. 


\subsection{Corporate governance effects}

\subsubsection{The rent extraction hypothesis}

When large shareholders control a company, they tend to extract private benefits from minority shareholders' wealth (e.g., Shleifer \& Vishny, 1997; Faccio et al., 2001; Villalonga \& Amit, 2006; Bena \& Hanousek, 2008). Gugler and Yurtoglu (2003) analyse the effect of dividend change announcements and dividend payouts in Germany. They show that dividends are indicators of conflict of interest between large and minority shareholders, and majority control reduces dividend payout. Bena and Hansousek (2008) investigate the medium and large privatised companies traded in Prague Stock Exchange and find that large shareholders extract rents from minority shareholders. The study also finds that the presence of a significant minority shareholder prevents rent extraction by increasing the dividend payout ratio. Mancinelli and Ozkan (2006) report a negative relationship between ownership concentration and dividend payouts in listed Italian companies. Similarly, Harada and Nguyen (2011) find the same relationship for listed companies in Japan. Casado, Burkert, Dávila, and Daniel (2016) investigate the listed non-financial Swiss companies. They find that in companies with multiple large shareholders, governance mechanisms and shareholder protection are improved to mitigate the rent extraction by the other large shareholders. They also show that improvement in governance mechanisms and shareholder protection is more when the large shareholders are not fiduciary but beneficiary. In his study of publicly listed Indonesian companies, Setia-Atmaja (2016) shows that dividend payouts are negatively affected by the family control supporting the rent extraction hypothesis. González et al. (2017) study six Latin American countries and find evidence for the monitoring role of a second large shareholder. In the case that ownership is concentrated and the largest shareholder is an individual, fewer dividends are paid to extract rent from minority shareholders (González et al., 2017). Another study by Tran, Alphonse, and Nguyen (2017) examines the effect of global financial crises on dividend policy and finds that the impacts of shareholder and creditor rights on dividend policy are lower in the post-crisis period. Tran et al. (2017) show that when the shareholder rights are stronger, creditor expropriation is more severe and vice versa.

Companies affiliated to BGs experience a value discount because of the agency costs that may arise due to managers' entrenchment and the expropriation of minority shareholders (Faccio et al., 2001). In an insider system of corporate governance such as the one in Turkey, there are few listed companies that have concentrated control (Demirag \& Serter, 2003). In this system, rent extraction by the controlling shareholder can be a severe agency problem (Agency Problem II), and the rent extraction hypothesis predicts that controlling families prefer to pay lower dividends to keep company resources under their control. Additionally, they can misuse company resources by investing in non-profitable projects that only benefit themselves (Anderson \& Reeb, 2003) or tunnelling resources to affiliated companies in which they have greater ownership rights. Within BGs, typical examples of expropriation are arm's length transactions, loans at favourable rates, cash retention through dividend policy, asset transfers, and ownership dilution among minority shareholders (La Porta et al., 2000). 


\subsubsection{The reputation building (substitution) and the outcome hypotheses}

Contrary to the predictions of the rent extraction hypothesis, families can also use dividends as a mechanism to build reputation. The reputation building hypothesis predicts higher dividend payments to alleviate minority shareholders' expropriation concerns (La Porta et al., 2000). High concentration of control by the largest shareholders erodes company reputation, and minority shareholders demand higher returns to supply capital (Faccio et al., 2001). Hence, dividend policy is used to alleviate expropriation concerns. Faccio et al. (2001) analyse the dividend behaviour of five Western Europe and nine East Asian countries in which concentrated control and group affiliation are abundant. They use ownership (cash flow) to control rights ratio $(\mathrm{O} / \mathrm{C})$ as a measure of expropriation by the controlling shareholders. They find that companies that are "tightly affiliated" to a BG pay higher dividends to alleviate the concerns about expropriation and to lower the cost of external financing. In companies that are "loosely affiliated" to a BG, investors are less alert to possibility of rent extraction by the controlling shareholders and press less for dividends. Therefore, in "loosely affiliated" BG companies, lower dividends are paid as the divergence between ownership and control rights of the controlling shareholder widens.

Setia-Atmaja, George, and Skully (2009) show that Australian family companies have higher dividend payout ratios, higher leverage and lower level of board independence than non-family companies. Even though Australia has a strong investor protection system, they find that family companies use dividends and debt as a substitute for low board independence supporting the reputation building hypothesis. De Cesari (2012) examine the listed non-financial Italian companies and show that share of cash dividends in total payout (i.e., cash dividends plus repurchases) increases as the wedge between control and cash flow rights of the controlling shareholder widens. There is also empirical evidence that companies in emerging countries with weak investor protection have higher dividend payouts for enhancing reputation irrespective of the company risk (Botoc \& Pirtea, 2014). Another study finds that as the stake of founding families increases, companies tend to have higher dividend payouts to create a reputation for the fair treatment of minority shareholders (Isakov \& Weisskopf, 2015). Kuo (2017) examines the listed Tai companies that are characterised by concentrated ownership. Kuo finds that when the separation between voting and cashflow rights of the controlling shareholder is high and when the CEO is affiliated with the controlling shareholder, companies use dividends to build reputation. In contrast, Baker, Kilincarslan, and Arsal (2018) survey managers of Borsa Istanbul companies on dividend policy and find that BIST companies do not use dividends for reputation building.

The outcome hypothesis, an alternative explanation in the literature, predicts that due to the pressure exerted by minority shareholders, dividend payouts are higher in countries with strong shareholder protection (La Porta et al., 2000; Jiraporn \& Ning, 2006). Further, the outcome hypothesis predicts that in countries with strong shareholder protection, shareholders should accept lower dividend payouts in high growth companies whereas in low growth companies, dividend payouts should be higher not to allow wasteful investments. In contrast, in countries with weak shareholder protection such a relationship between dividend payouts and growth opportunities is not expected (La Porta et al., 2000). La Porta et al. (2000) examine a heterogenous sample of 33 countries having different levels of minority shareholder 
rights and find support for the outcome hypothesis. Adjaoud and Ben-Amar (2010) study the listed Canadian companies that have concentrated ownership in a strong shareholder protection system. At the company level, they find a positive relationship between corporate governance quality and dividend payouts supporting the outcome hypothesis. Byrne and O'Connor (2012) show that creditor rights are more important than shareholder rights in determining the dividend policy and find empirical support for the outcome hypothesis in countries with strong creditor rights. However, in countries with weak creditor rights, companies pay out lower dividends regardless of the strength of shareholder rights.

\subsection{Dividend stability, capital structure, life-cycle, free cash flow and tax effects}

Investors prefer dividends to counter market imperfections and information asymmetry (Lintner, 1962; Gordon, 1963). In his prominent article, Lintner (1956) finds that companies determine a target dividend payout ratio that allow them to continue their capital investments and growth in the long term. In addition, Lintner shows that managers pursue stable dividend policies and avoid unsustainable dividend increases. Insiders have access to superior information compared to outsiders. Hence, in the light of Lintner's findings, investors gain insights about a company's future earnings from dividend announcements (i.e., the signalling effect). Investors (outsiders) react to dividend changes and managers smooth dividends over time to avoid stock price volatility (Lintner, 1956). Bulan and Hull (2013) analyse the effect of financial covenant violation on dividends. In line with the pioneering findings in Lintner's (1956) study, they show that managers are reluctant to cut dividends until they are forced to do so by the creditors. Benavides, Berggrun, and Perafan (2016) investigate the relationship between governance and dividend adjustments. They find that companies in countries with better governance scores smooth their dividends more.

Capital structure also affects dividend policy. The two important theories of capital structure, namely pecking order theory and trade-off theory, have opposite predictions on dividend policy. The former argues that there is a negative relationship between leverage and dividend payouts whereas the latter predicts a positive relationship. Alzahrani and Lasfer (2012) find empirical results supporting the pecking order theory in 24 OECD countries, whereas Botoc and Pirtea (2014) find empirical results supporting the trade-off theory in 16 emerging countries.

The life-cycle theory argues that the costs of paying dividends decrease and the benefits of paying dividends increase as companies become more mature (H. DeAngelo, L. DeAngelo, \& Stulz, 2006). Brockman and Unlu (2011) find cross-country empirical evidence supporting the life-cycle theory. Similarly, Coulton and Roddock (2011) report that Australian companies' payout policies can be explained by the life-cycle theory. Thanatawee (2011) study the listed Thai companies and find empirical evidence supporting both the life-cycle and the free cash flow theories. The free cash flow theory argues that companies should pay out excess cash flows as dividends since managers tend to use excess cash flows for their private benefits and tend to overinvest in pursuit of building an empire of companies (Jensen, 1986). In support of the overinvestment argument, Chen, Yong, and Xiaodong (2016) show that the overinvestments of the listed non-financial Chinese companies are related to the current free 
cash flow, and as the free cash flow increases, the overinvestment urge gets higher. Iturriaga and Crisóstomo (2010) show that, companies use dividends as a disciplinary mechanism to reduce excess cash under the control of managers. Karpavičius and Yu (2017) investigate the non-financial U.S. companies, and find companies that have institutional owners are closely monitored and hence, have lower leverage and lower dividend payouts.

In his prominent "The Dividend Puzzle" article, Black (1976) raises the question of why companies keep paying dividends even though dividend taxation is higher than capital gains taxation. The tax preference hypothesis argues that if capital gains taxes are lower than dividend income taxes, investors may prefer companies that have no dividends or low dividend payouts (Brennan, 1970; Elton \& Gruber, 1970; Litzenberger \& Ramaswamy, 1979). The tax clientele effect hypothesis argues that investors choose between high and low dividend paying shares depending on their tax positions (Miller \& Modigliani, 1961). Desai and Jin (2011) find that institutional investors that do not prefer dividends due to higher taxation are less likely to invest in dividend paying companies and companies care about their investors' tax preferences when deciding on their payout policies. In another study, Dahlquist et al. (2014) investigate the Swedish stock market companies. They find that tax neutral investors, investment funds and partnerships behave in line with the tax clientele hypothesis whereas businesses and individuals do not. Jacob and Michaely (2017) examine the dividend tax responsiveness and how it is affected by agency issues and conflicting objectives among shareholders. They find that taxation is the most influential effect but agency conflicts reduce its impact significantly. In contrast, Moortgat, Annaert, and Deloof (2017) examine listed Belgian firms during a long sample period (1838-2018) and find that the impact of changes in investor protection and taxation on dividend policy is very limited.

\section{Turkish business settings and hypotheses}

In developing economies, intermediaries in the capital, labour and product markets are not efficient or are not sufficiently common. BG-affiliated companies can benefit from internal mechanisms that can substitute for these inefficient and insufficient markets (Khanna \& Yafeh, 2010). In particular, internal capital markets can be used to transfer capital among the affiliated BG companies (Friedman, Johnson, \& Mitton, 2003), and such managerial decisions can potentially hurt minority shareholders' interests. Additionally, Adaoglu (2000) finds that Borsa Istanbul companies follow unstable dividend policies. Hence, this can be interpreted as an indirect evidence that managers of Borsa Istanbul companies do not consider the signalling effects in determining their dividend policy but consider the effects of dividend payments on internal financing that has a vital importance in a country of limited capital sources and access.

Typically, BGs in Turkey are organized around a holding company controlled by a family or by a coalition of families (Demirag \& Serter, 2003; Yurtoglu, 2003), which allows these families to maintain centralized control over BG companies' activities and resources. This encourages the formation of a capital unification, which creates an internal capital market. Besides, the holding control structure provides taxation advantages (Yurtoglu, 2000). 
However, expropriation mechanisms are stronger in holding BGs than in non-holding BGs as the centralized control in holding BGs creates a stronger internal capital market and reduces their need for external financing, which results in less monitoring by financial institutions (Easterbrook, 1984) and facilitates expropriation by controlling families, especially in the presence of CEMs. Many cases of corruption, insider trading, share dilution, asset stripping and market manipulation in Turkish holding BGs were reported in the 1990s and 2000s (Yurtoglu, 2003).

The separation between control and ownership rights is a result of CEMs, such as pyramid structure and dual class shares. Families use pyramid structure and dual class shares to control companies in BGs (Demirag \& Serter, 2003). ${ }^{2}$ In BGs with a pyramid structure, rent extraction concerns are expected to be higher than in those without a pyramid structure (Johnson, La Porta, Lopez-De-Silanes, \& Shleifer, 2000; Bertrand, Mehta, \& Mullainathan, 2002). Dual class shares assign higher voting rights to one class of shares, and studies show that dual class shares allow controlling shareholders to have private benefits of control which would not be possible with single class shares (Masulis, Wang, \& Xie, 2009).

Turkey is a civil law country, and it is characterised by a weak shareholder protection setting (Mitton, 2004; Botoc \& Pirtea, 2014). In countries where shareholder protection is weak, minority shareholders are not powerful enough to extract dividends (La Porta et al., 2000). Therefore, the outcome hypothesis is unlikely to explain the dividend payout behaviour of family controlled Borsa Istanbul companies. Considering the weak shareholder protection setting, stronger expropriation mechanisms and stronger internal capital markets for holding BG companies, we hypothesize that:

Hypotheses: There is a negative relationship between CEMs (i.e., the total (control-ownership) wedge, the pyramid wedge, and the dual share wedge) and dividend payout for holding BG companies and vice-versa for non-holding BG companies.

In other words, the rent extraction hypothesis is more likely to hold for holding BG companies, while the reputation building mechanism is more likely to hold for non-holding BG companies.

\section{Data and methodology}

\subsection{Data}

We examine all companies listed on the BIST National Market during the 2010-2017 period. We exclude financial, utility and sport club companies, which are subject to different regulations and accounting standards. Our sample covers the 2010-2017 period because annual reports prior to 2009 are not comprehensive. Moreover, in 2009, mandatory dividend payment was abolished for public companies (Adaoglu, 2008). We hand-collect data on ownership structure from annual financial reports and the attendance/voting lists of general shareholders' meetings published in the Public Disclosure Platform (PDP) and company websites. All market and financial statement data are collected from StockGround ${ }^{\circ}$ database program.

\footnotetext{
${ }^{2}$ We find that only 2 of 141 family controlled companies have direct cross shareholding which is another CEM.
} 
Subsequently, we identify the family controlled BG companies at the ultimate level. Following Faccio et al.s (2001) definition of BG, a company is classified as a "business group company" if one of the following criteria holds: i) The company is controlled by a shareholder through pyramiding; ii) the company controls another company in the sample; iii) the company has the same ultimate shareholder as one or more companies in the sample; or iv) the ultimate shareholder of the company is a widely held company or widely held financial company.

We define a BIST company as a family-controlled company if it meets one of the following conditions. Given a $20 \%$ threshold level of control rights, (1) the ultimate owners are from the same family; (2) the ultimate owners are from the coalition of at least two different families; or (3) the ultimate owner is an individual large owner (e.g., Sacristán-Navarro, Gómez-Anson, \& Cabeza). ${ }^{3}$ We also trace family members through their surnames and marriages, and treat them collectively in our calculations.

In total, we identify 141 family-controlled BG companies. We group each company as either a holding or a non-holding BG company by tracing the presence of a controlling holding company in their ownership structures. As a final step, we exclude companies with insufficient accounting data and newly listed companies with one year of data. As in the dividend literature (e.g., Adjaoud \& Ben-Amar, 2010), we also exclude company-level observations for years in which it had negative dividend payout. Ultimately, we have 901 company-year observations for a total of 134 companies.

\subsection{Models and methodology}

We use panel random effects Tobit estimation because the dependent variable is censored at zero and the Likelihood-ratio tests favour the random effects model rather than the pooled model. The estimated model is specified as follows:

$$
\begin{aligned}
& D I V / E A R N_{i, t}=\alpha+\beta_{1} W_{E D G E} E_{i, t}+\beta_{2} H O L_{i, t}+\beta_{3}\left(H O L_{i, t} \times W E D G E_{i, t}\right)+ \\
& \beta_{4} N B_{i, t}+\beta_{5} F B_{i, t}+\beta_{6} F D U M M Y_{i, t}+\beta_{7} A G E_{i, t}+\beta_{8} L_{E V E R_{i, t}}+\beta_{9} R O A_{i, t}+ \\
& \beta_{10} \operatorname{SIZE}_{i, t}+\beta_{11} G R_{i, t}+\sum_{1}^{T} \delta_{i} Y E A R_{i, t}+\sum_{1}^{J} \gamma_{j} I N D_{j, t}+\varepsilon_{i t} \text {. }
\end{aligned}
$$

We use the dividend payout ratio $(D I V / E A R N)$ as the dependent variable. ${ }^{4}$ To avoid the potential outlier effects in estimation, we winsorise the dividend payout ratio at $1^{\text {st }}$ and $99^{\text {th }}$ percentiles. Depending on the selected model, 'WEDGE' stands for the total wedge, pyramid wedge and dual share wedge. The HOL dummy variable is equal to 1 if the intermediary controlling company is a holding company and is used to evaluate the effect of a holding company as a control entity on dividend payouts. We also add interactions between the holding dummy variable $(H O L)$ with the total wedge $(C / O)$, pyramid wedge $(C / V)$ and dual share wedge $(V / O)$ to investigate their respective effects. To further examine the effect

\footnotetext{
3 In literature, the control threshold limit is either $10 \%$ or $20 \%$. The appropriate control threshold limit used in the study is $20 \%$ since there is no family controlled company in our sample having a control rights range of 0-19.99\%.

${ }^{4}$ Borsa Istanbul companies have been legally allowed to repurchase their stocks since August 2011. However, repurchases are not used as substitutes for cash dividends (Pirgaip \& Karacaer, 2015).
} 
of CEMs, we add indicators of control achieved through the board. These are the board size $(N B)$, the ratio of family members on the board $(F B)$ as well as a foreign dummy variable (FDUMMY) to capture the effect of a foreigner's presence in the control coalition. CEMs are fully explained in the following section.

Based on previous literature (e.g., Faccio et al., 2001; Mancinelli \& Ozkan, 2006; Gonzales et al., 2014), we add five control variables for company characteristics, namely return on assets $(R O A)$, leverage (LEVER) and growth opportunities (GR), firm age (AGE) and firm size $(S I Z E)$. Finally, we add year dummies (YEAR) to control for the effect of unobserved timevarying factors (Chen, Cheung, Stouraitis, \& Wong, 2005), and industry dummies (IND) to control for industry-specific effects. We provide detailed descriptions of all variables in the appendix.

As the limitation of our study, we echo the sentiment of Villalonga and Amit (2009): "As a caveat to the interpretation of our results, we acknowledge that the choice of one mechanism or another by founding families is endogenous, which raises the possibility of reverse causation" (p. 3088). However, in corporate governance econometrics, finding the correct instrumental variables for different control-enhancing mechanisms is still an unresolved problem for empirical studies (e.g., Lins, 2003; Adams \& Ferreira, 2008). For instance, Villalonga and Amit (2009) state that their sample's ownership structure is stable over time and that CEMs had already existed at the beginning of their sample period; therefore, it is very unlikely that a reverse causality problem exists. We find the same empirical observation for our sample. The ownership and control structures are significantly stable over time similar to the findings of Yurtoglu (2003) for Turkey. Using lagged explanatory variables is not an effective methodology to tackle the endogeneity problem if the changes in the main hypothesized variables are minimal or zero.

\subsection{CEM explanatory variables}

Control rights $(C)$ are measured by the direct link method at the $20 \%$ threshold level. ${ }^{5}$ We sum control rights held by the ultimate owner directly and control rights held by other controlled companies (La Porta, Lopez-De-Silanes, Shleifer, A., \& Vishny, 1999; Lins, 2003). The ownership $(O)$ variable represents the fraction of dividends received by the ultimate owner; it is the sum of direct cash flow (dividend) rights and cash flows through pyramids and cross-shareholdings (Almeida et al., 2007). For companies with pyramid control chains, we calculate indirect cash flow rights by multiplying the percentage of equity held by the ultimate family along each control chain and then adding these percentages.

Subsequently, we precisely decompose the total wedge $(C / O)$ into the pyramid wedge $(\mathrm{C} / \mathrm{V})$ and dual share wedge $(\mathrm{V} / \mathrm{O})$ following the specific wedge calculation developed by Villalonga and Amit (2009). The $C / V$ ratio represents the divergence between control and voting rights. " $V$ " stands for the percentage of votes owned by the ultimate owner through direct and/or indirect chains of ownership as a percentage of total votes outstanding. The $V / O$

\footnotetext{
5 For Turkish companies, Yurtoglu $(2000,2003)$ use the direct link method based on the finding that an active merger and acquisition market does not exist, and that the ownership structure does not significantly change over time.
} 
ratio represents the dual share wedge. In ratio format, the decomposition of the control-toownership ratio $(\mathrm{C} / \mathrm{O})$ is as follows:

$$
C / O=C / V \times V / O
$$

We demonstrate the preceding wedge calculations by using the ownership structure of "Link Bilgisayar A.Ş (LINK)," a family controlled holding BG company. The ownership structure is shown in Figure 1 (Panel A). LINK is ultimately owned by Kasaroglu family, and the control is achieved by both pyramid wedge and dual share wedge. This family controls 69\% (C2) of Link Holding A.Ş., with same amount of cash flow rights (O2). Then, Link

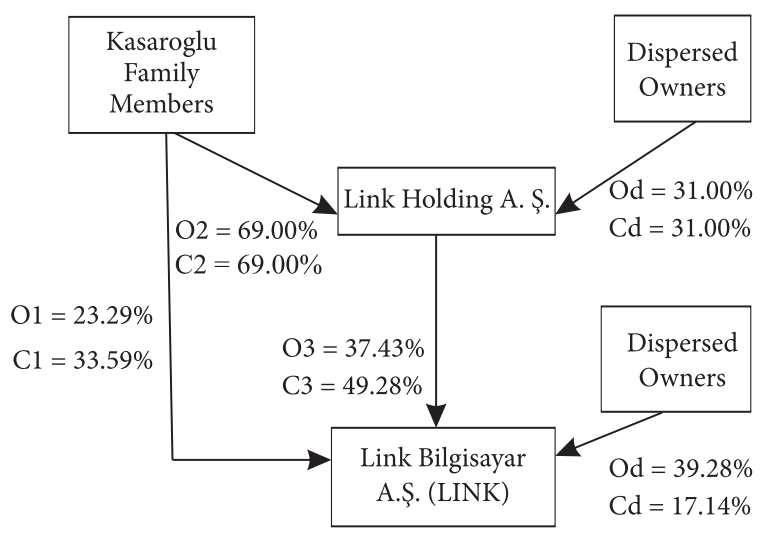

Panel A. Ownership structure of a family controlled holding BG company, 'LINK'.

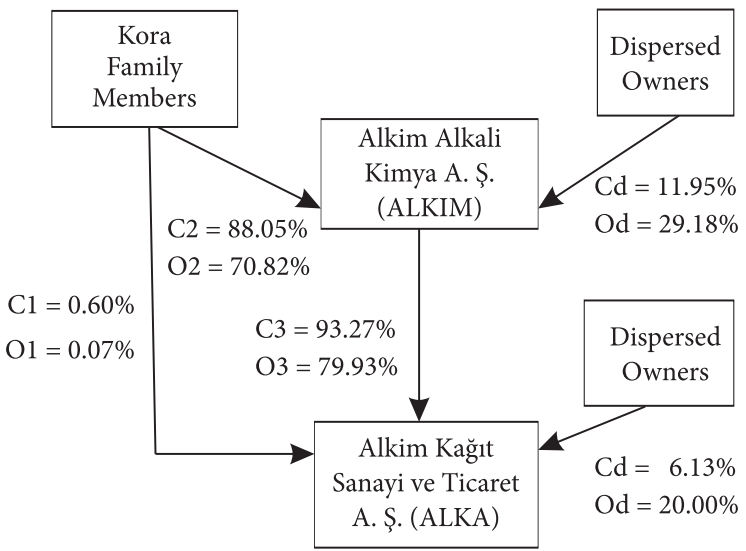

Panel B. Ownership structure of a family controlled non-holding BG company, "ALKA".

Figure 1. Ownership structures of a holding BG company and a non-holding BG company (source: authors' calculations)

Notes: This figure shows the ownership and control rights of a holding BG company "Link Bilgisayar A.Ş.," and a non-holding BG company "Alkim Kağıt Sanayi ve Ticaret A.Ş." "C" shows the control (voting) rights, and "O" shows the ownership (cash flow) rights. 
Holding A. Ş. controls LINK. It controls $49.28 \%$ (C3) of total votes outstanding and has ownership rights of $37.43 \%(\mathrm{O} 3)$. The family also controls LINK directly, and a control-ownership wedge is present due to the dual class shares. $\mathrm{O} 1$ is $23.29 \%$ and $\mathrm{C} 1$ is $33.59 \%$.

In dual share wedge (V/O) calculations, we calculate "V" by multiplying $\mathrm{C} 2$ and $\mathrm{C} 3$ and adding $\mathrm{C} 1$. "V" is equal to $67.59 \%$. "O" is the product of $\mathrm{O} 2$ and $\mathrm{O} 3$, and we add the resulting value of $49.12 \%$ to $\mathrm{O} 1$. We add C1 and C3 resulting in a total control value of $82.87 \%$ (C). We can decompose the total wedge, as in equation 2, into pyramid wedge and dual share wedge as follows. The total wedge, pyramid wedge and the dual share wedge are $1.69,1.23$ and 1.38 respectively. The demonstration of Eq. (2) for this company is as follows:

$(82.87 \% / 49.12 \%)=(82.87 \% / 67.59 \%)$ multiplied by $(67.59 \% / 49.12 \%)$, $1.69=1.23$ multiplied by 1.38 .

In Figure 1 (Panel B), we show the ownership structure of a family-controlled non-holding BG company, "Alkim Kağıt Sanayi ve Ticaret A.Ş. (ALKA)", which is ultimately controlled by the Kora family. ALKA is controlled through directly owned shares and through a nonholding company, Alkim Alkali Kimya A.Ş. (ALKIM). The total wedge, pyramid wedge and dual share wedge are $1.66,1.13$ and 1.46 respectively.

\section{Empirical results}

\subsection{Descriptive statistics}

In Table 1, we show the descriptive statistics for the unwinsorised dependent variable in Panel A, the CEM variables in Panel B, and the control variables in Panel C. We also show the $\mathrm{t}$-test results for the differences in means of the variables between holding and non-holding BG companies. We have a higher mean dividend payout ratio for holding BG companies, and the difference is only statistically significant at $10 \%$ significance level. For holding and nonholding BG companies, there is no significant difference in the mean $\mathrm{C} / \mathrm{O}$ ratios. In line with the expectation for a holding control structure, we detect a statistically significantly higher value in the mean C/V ratio (pyramid wedge) for holding BG companies. Non-holding BG companies have a higher mean $\mathrm{V} / \mathrm{O}$ ratio (dual share wedge) than holding BG companies. Furthermore, non-holding BG companies have smaller board size on average, and family representation on boards is higher. Controlling foreign-family coalition (FDUMMY) is found in $26 \%$ of holding BG companies, whereas it is only $11 \%$ for non-holding BG companies.

Regarding control variables, Panel $\mathrm{C}$ shows that on average, holding BG companies are older, larger and more profitable than non-holding BG companies. We do not detect any statistically difference in mean leverage and growth opportunities.

Table 2 shows the correlation matrix. The results show that, among CEM variables, the pyramid wedge $(\mathrm{C} / \mathrm{V})$ and the board size $(\mathrm{NB})$ have a positive relationship with the dependent variable, namely, the dividend payout ratio (DIV/EARN). The total wedge $(\mathrm{C} / \mathrm{O})$, the dual share wedge $(\mathrm{V} / \mathrm{O})$ and the ratio of family members on the board (FB) have a negative relationship with the dividend payout ratio. The foreign dummy (FDUMMY) and the holding dummy (HOL) have a positive relationship with the dividend payout, while age (AGE), profitability (ROA), size (SIZE), and growth opportunities (GR) have a positive relationship 


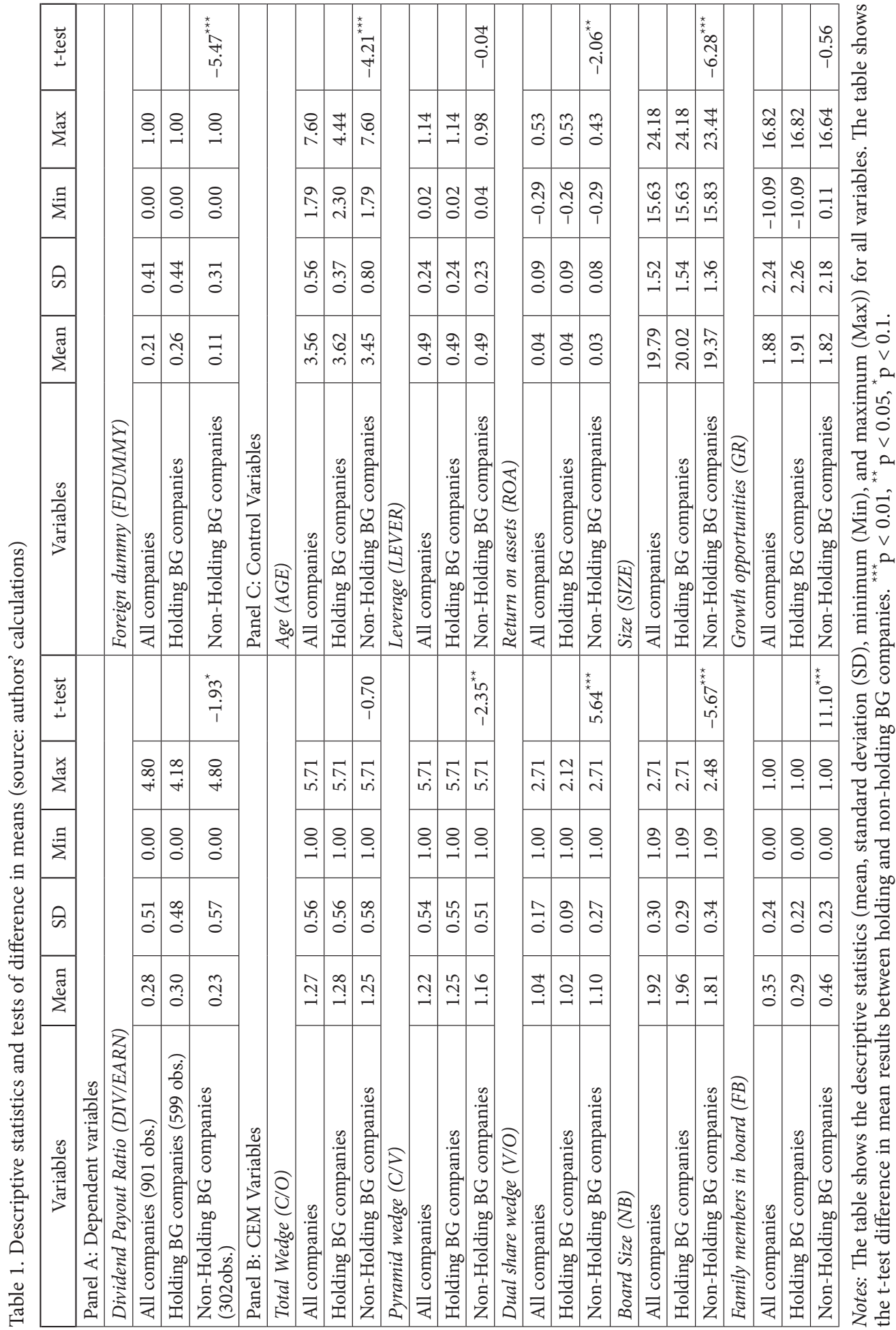




\begin{tabular}{|c|c|c|c|c|c|c|c|c|c|c|c|c|}
\hline 孞 & & & & & & & & & & & & $\underset{-}{8}$ \\
\hline 窉 & & & & & & & & & & & $\stackrel{8}{8}$ & $\stackrel{\star}{a}$ \\
\hline$\underset{\swarrow}{\mathbb{1}}$ & & & & & & & & & & 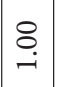 & $\stackrel{*}{\circ}$ & *at \\
\hline 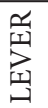 & & & & & & & & & $\underset{8}{\circ}$ & *a & $\stackrel{*}{\pi}$ & ก̊ \\
\hline 兒 & & & & & & & & $\underset{-}{\stackrel{8}{-}}$ & $\begin{array}{l}2 \\
0 \\
0\end{array}$ & $\begin{array}{l}* \\
0 \\
0 \\
0\end{array}$ & $\stackrel{*}{\circ}$ & 苗 \\
\hline 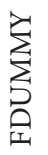 & & & & & & & $\stackrel{8}{8}$ & $\begin{array}{l}\dot{H} \\
0 \\
0\end{array}$ & $\begin{array}{l}+ \\
0 \\
0\end{array}$ & $\mid \begin{array}{c}* \\
0 \\
0 \\
0\end{array}$ & $\stackrel{*}{1}$ & $\stackrel{*}{*} \stackrel{\infty}{1}$ \\
\hline$\stackrel{\varphi}{a}$ & & & & & & $\stackrel{8}{-}$ & $\overrightarrow{0}$ & $\begin{array}{l}* \\
0 \\
0 \\
0\end{array}$ & $\begin{array}{l}m \\
0 \\
0 \\
1\end{array}$ & $\begin{array}{l}H \\
0\end{array}$ & $\stackrel{*}{m}$ & å \\
\hline$\tilde{z}$ & & & & & $\stackrel{8}{8}$ & 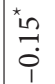 & たo & $\begin{array}{l}* \\
0 \\
0 \\
0 \\
0\end{array}$ & $\begin{array}{l}n \\
0 \\
0\end{array}$ & ‥ & *n & ㅊ. \\
\hline 렆 & & & & $\stackrel{8}{8}$ & $\stackrel{*}{0}$ & $\begin{array}{l}* \\
1 \\
n \\
0 \\
i\end{array}$ & $\stackrel{*}{\infty}$ & * & $\begin{array}{l}8 \\
0 \\
0\end{array}$ & 列 & $\vec{*}$ & 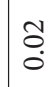 \\
\hline$\frac{0}{>}$ & & & ن & *a & $\begin{array}{l}n \\
0 \\
0\end{array}$ & $\stackrel{*}{\circ} \stackrel{0}{0}$ & *0 & $\begin{array}{l}* \\
\tilde{n} \\
0 \\
1\end{array}$ & $\begin{array}{l}* \\
0 \\
0 \\
0 \\
1\end{array}$ & * & ㅊ. & 8 \\
\hline$z$ & & $\stackrel{8}{8}$ & $\begin{array}{l}n \\
0 \\
0 \\
1\end{array}$ & 齐文 & * & $\stackrel{*}{*} \underset{1}{0}$ & ô. & 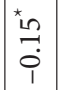 & $\begin{array}{c}{ }^{*} \\
\stackrel{10}{2} \\
0 \\
0 \\
1 \\
1\end{array}$ & $\begin{array}{l}n \\
0 \\
0 \\
1\end{array}$ & 苾 & $\begin{array}{l}\text { th } \\
0 \\
\dot{1}\end{array}$ \\
\hline$\frac{0}{u}$ & $\stackrel{8}{8}$ & 象 & $\stackrel{*}{\infty}$ & Õ & $\stackrel{n}{0}$ & 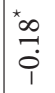 & ö & 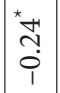 & ㅊ. & 藏 & $\stackrel{*}{m}$ & 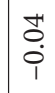 \\
\hline 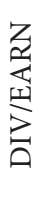 & $\begin{array}{l}0 \\
\stackrel{0}{0} \\
\dot{1}\end{array}$ & ठே. & 齐 & *0 & ma & $\begin{array}{l}* \\
\infty \\
0 \\
0 \\
1 \\
1\end{array}$ & * & $\begin{array}{l}+ \\
0 \\
0\end{array}$ & 는 & a & ڤે & $\stackrel{*}{10}$ \\
\hline 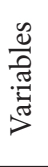 & $\frac{0}{u}$ & $z$ & $\stackrel{0}{>}$ & 完 & 吕 & 里 & 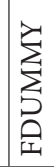 & 恣 & 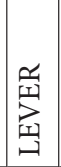 & 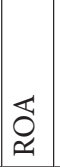 & 离 & 怂 \\
\hline & \multicolumn{7}{|c|}{ 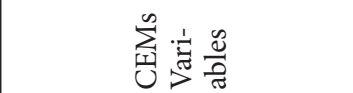 } & \multicolumn{5}{|c|}{ 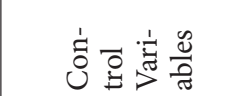 } \\
\hline
\end{tabular}


with the dividend payout ratio. In contrast, leverage (LEVER) has a negative relationship with this ratio. Except for the total wedge $(\mathrm{C} / \mathrm{O})$ and its component $(\mathrm{C} / \mathrm{V})$, we do not observe high levels of correlation among other variables for potential multicollinearity problems. There is a high level of correlation $(0.94)$ between the total wedge $(\mathrm{C} / \mathrm{O})$ and its component, the pyramid wedge $(\mathrm{C} / \mathrm{V})$. To avoid multicollinearity problems, the $\mathrm{C} / \mathrm{O}$ variable is not estimated together with its components $\mathrm{V} / \mathrm{O}$ and $\mathrm{C} / \mathrm{V}$ variables in the following multivariate analysis.

\subsection{Multivariate analysis}

Table 3 presents the results of random effects Tobit estimation for Eq. (1). In Model 1, we capture the total wedge effect $(\mathrm{C} / \mathrm{O})$ on the dividend payout ratio, while in Models 2 and 3 , we capture the effect of the pyramid wedge $(\mathrm{C} / \mathrm{V})$ and the dual share wedge $(\mathrm{V} / \mathrm{O})$ on dividend payouts, respectively. We observe the effects of both component wedges together in Model 4. Statistically, the Wald $\mathrm{chi}^{2}$ test results for all models indicate that all coefficients are simultaneously (jointly) different than zero.

Focusing on the wedges, the total wedge is statistically insignificant in Model 1. Similarly, the pyramid wedge $(\mathrm{C} / \mathrm{V})$ and the dual share wedge $(\mathrm{V} / \mathrm{O})$ components are statistically insignificant in Models 2, 3, and 4. Since we have interactions between the holding dummy variable and the wedge variables in our models, the coefficients of the total wedge $(\mathrm{C} / \mathrm{O})$, the pyramid wedge $(\mathrm{C} / \mathrm{V})$ and the dual share wedge $(\mathrm{V} / \mathrm{O})$ measure the respective effects of wedges on the dividend payout ratio of non-holding BG companies. The statistically insignificant results show that the total wedge $(\mathrm{C} / \mathrm{O})$, the pyramid wedge $(\mathrm{C} / \mathrm{V})$ and the dual share wedge $(\mathrm{V} / \mathrm{O})$ do not affect the dividend payout decisions of non-holding BG companies.

To examine the effect of control wedges on the dividend payout ratio of holding $\mathrm{BG}$ companies, we interact wedge variables with the holding dummy variable. The sum of the coefficients of wedges with the coefficients of their respective interaction terms gives us the net effect of the total wedge $(\mathrm{C} / \mathrm{O})$, the pyramid wedge $(\mathrm{C} / \mathrm{V})$ and the dual share wedge $(\mathrm{V} / \mathrm{O})$ on the dividend payout ratio of holding BG companies. In Model 1, since the coefficient of total wedge $(\mathrm{C} / \mathrm{O})$ is statistically insignificant, for holding $\mathrm{BG}$ companies, the net effect of total wedge $(\mathrm{C} / \mathrm{O})$ is the coefficient of statistically significant interaction term $\left(\mathrm{HOL}^{\star} \mathrm{C} / \mathrm{O}\right)$, -0.162 . Similarly, in Models 2 and 4, since the coefficients of pyramid wedge $(\mathrm{C} / \mathrm{V})$ are statistically insignificant. The statistically significant net effects of pyramid wedge $\left(\mathrm{HOL}^{\star} \mathrm{C} / \mathrm{V}\right)$ for holding BG companies are -0.173 and -0.172 , respectively. In Models 3 and 4 , the dual share wedges $(\mathrm{V} / \mathrm{O})$ and their interaction terms $\left(\mathrm{HOL}^{*} \mathrm{~V} / \mathrm{O}\right)$ are statistically insignificant.

Our results for Models 1, 2 and 4 show that in holding BG companies, as the total wedge and the pyramid wedge increase, the incentives for controlling families to extract private benefits increase and dividend payouts decrease. The results also show that the pyramid wedge effect is stronger than the total wedge effect. These findings are in line with the rent extraction hypothesis and support our hypothesis for the family-controlled holding BG companies. However, there is no empirical support for the effect of dual share wedge on the dividend payout of holding BG companies.

In Models 1 and 2, the coefficients of the holding dummy variables (HOL) are positive and statistically significant at 10\% significance level but in Models 3 and 4, the coefficients of HOL are statistically insignificant. Hence, we do not have strong empirical evidence that 
Table 3. CEMs and dividend payouts in family controlled BG companies (source: authors' calculations)

\begin{tabular}{|c|c|c|c|c|c|c|}
\hline & \multirow{3}{*}{$\begin{array}{c}\text { Model } 1 \\
\text { Total } \\
\text { Wedge }\end{array}$} & & & \\
\hline & & & & Model 2 & Model 3 & Model 4 \\
\hline & & & & $\begin{array}{l}\text { Pyramid } \\
\text { Wedge }\end{array}$ & $\begin{array}{l}\text { Dual-class } \\
\text { Wedge }\end{array}$ & $\begin{array}{l}\text { Pyramid \& Dual- } \\
\text { class Wedge }\end{array}$ \\
\hline \multirow{10}{*}{ 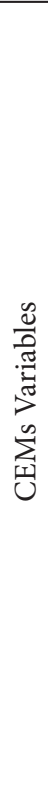 } & Total Wedge & $\mathrm{C} / \mathrm{O}$ & $0.040(1.04)$ & & & \\
\hline & $\begin{array}{l}\text { Pyramid } \\
\text { Wedge }\end{array}$ & $\mathrm{C} / \mathrm{V}$ & & $0.047(1.19)$ & & $0.047(1.19)$ \\
\hline & $\begin{array}{l}\text { Dual Share } \\
\text { Wedge }\end{array}$ & $\mathrm{V} / \mathrm{O}$ & & & $-0.026(-0.15)$ & $-0.019(-0.11)$ \\
\hline & Holding & $\mathrm{HOL}$ & $0.198^{*}(1.68)$ & $0.206^{*}(1.76)$ & $-0.150(-0.35)$ & $0.132(0.30)$ \\
\hline & $\begin{array}{l}\text { Holding } \\
\text { Total Wedge }\end{array}$ & $\mathrm{HOL}^{*} \mathrm{C} / \mathrm{O}$ & $-0.162^{*}(-1.88)$ & & & \\
\hline & $\begin{array}{l}\text { Holding* } \\
\text { Pyramid } \\
\text { Wedge }\end{array}$ & $\begin{array}{l}\mathrm{HOL} \\
{ }^{*} \mathrm{C} / \mathrm{V}\end{array}$ & & $-0.173^{* *}(-1.97)$ & & $-0.172^{*}(-1.95)$ \\
\hline & $\begin{array}{l}\text { Holding* } \\
\text { Dual Share } \\
\text { Wedge }\end{array}$ & $\begin{array}{l}\mathrm{HOL}^{*} \\
\mathrm{~V} / \mathrm{O}\end{array}$ & & & $0.137(0.33)$ & $0.070(0.17)$ \\
\hline & Board Size & NB & $0.237^{* * *}(3.95)$ & $0.240^{\star * *}(4.01)$ & $0.242^{* * *}(3.98)$ & $0.242^{* * *}(4.00)$ \\
\hline & $\begin{array}{l}\text { Family Mem- } \\
\text { bers in Board }\end{array}$ & FB & $\begin{array}{l}-0.077 \\
(-1.00)\end{array}$ & $-0.077(-1.00)$ & $-0.054(-0.71)$ & $-0.077(-0.99)$ \\
\hline & $\begin{array}{l}\text { Foreign } \\
\text { Dummy }\end{array}$ & $\begin{array}{l}\text { FDUM- } \\
\text { MY }\end{array}$ & $0.040(1.07)$ & $0.041(1.10)$ & $0.035(0.94)$ & $0.041(1.10)$ \\
\hline \multirow{7}{*}{ 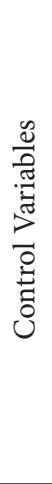 } & Age & AGE & $-0.059(-1.11)$ & $-0.060(-1.13)$ & $-0.054(-1.01)$ & $-0.060(-1.10)$ \\
\hline & Leverage & LEVER & $\begin{array}{c}-0.477^{* * *} \\
(-4.80)\end{array}$ & $\begin{array}{c}-0.476^{* * *} \\
(-4.82)\end{array}$ & $-0.486^{* * *}(-4.88)$ & $-0.477^{* * *}(-4.81)$ \\
\hline & Profitability & ROA & $0.564^{* * *}(3.27)$ & $0.564^{* * *}(3.28)$ & $0.567^{* * *}(3.30)$ & $0.564^{* * *}(3.28)$ \\
\hline & Size & SIZE & $0.073^{* * *}(4.14)$ & $0.072^{* * \star}(4.15)$ & $0.076^{* * *}(4.29)$ & $0.072^{* * *}(4.15)$ \\
\hline & $\begin{array}{l}\text { Growth Op- } \\
\text { portunities }\end{array}$ & GR & $0.006(0.77)$ & $0.006(0.80)$ & $0.007(0.86)$ & $0.006(0.81)$ \\
\hline & Year Effect & & Yes & Yes & Yes & Yes \\
\hline & $\begin{array}{l}\text { Industry } \\
\text { Effect }\end{array}$ & & Yes & Yes & Yes & Yes \\
\hline \multicolumn{3}{|c|}{ Number of observations } & 901 & 901 & 901 & 901 \\
\hline \multicolumn{3}{|c|}{ Left censored observations } & 521 & 521 & 521 & 521 \\
\hline \multicolumn{3}{|c|}{ Wald chi ${ }^{2}$} & $122.48^{* * *}$ & $123.67^{* * *}$ & $120.12^{* * *}$ & $123.97^{* * *}$ \\
\hline \multicolumn{3}{|c|}{ Likelihood-ratio } & $198.80^{* * *}$ & $195.75^{* * *}$ & $200.90^{* * *}$ & $191.09^{* * *}$ \\
\hline
\end{tabular}

Notes: Regression coefficients represent the marginal effects on the latent variable $y . \mathrm{z}$ statistics are in parentheses, ${ }^{* * *} \mathrm{p}<0.01,{ }^{* *} \mathrm{p}<0.05,{ }^{*} \mathrm{p}<0.1$. 
holding BG companies have higher dividend payouts than non-holding BG companies, ceteris paribus. Focusing on the estimation results for board CEMs, we find a positive relationship between board size and dividend payouts. This is in line with other studies' findings for countries with weak investor protection settings (e.g., Bradford, Chen, \& Zhu, 2013; González et al., 2014). Control enhancement through the board of directors is typically achieved by family members' dominance on the board (Chen \& Nowland, 2010). However, companies with a greater number of board members payout more dividends and can indicate less control in board decisions by family members. Statistically, FB and FDUMMY do not affect the dividend payouts of family-controlled BG companies.

SIZE and ROA are statistically significant in all models with positive signs. Larger and more profitable companies pay out more dividends. Size is used as a proxy for better financial market access (Aivazian, Booth, \& Cleary, 2003). Larger companies have better market access enabling them to pay higher dividends. In line with previous studies (e.g., Alzahrani \& Lasfer, 2012), we find that leverage affects the dividend payout ratio negatively due to capital constraints. When companies have profitable investment opportunities, they retain cash for these investments, and a negative relationship between growth opportunities and dividend payout ratio is expected. In contrast to previous findings (e.g. Mitton, 2004; Alzahrani \& Lasfer, 2012), we do not find a statistically significant effect of growth opportunities on dividend payouts. Since mature companies have fewer attractive investment opportunities, better access to capital markets and steady earnings, they are expected to pay higher dividends (Grullon, Michaely, \& Swaminathan, 2002; H. DeAngelo \& L. DeAngelo, 2006). In contrast to previous findings (e.g., Alzahrani \& Lasfer, 2012; González et al., 2014), AGE, a proxy for the life cycle, is found to be statistically insignificant. ${ }^{6}$

\subsection{Robustness results}

For the robustness of our results, we estimate Eq. (1) for the two sub-samples, holding and non-holding BGs, separately. In Table 4, we report the random effects Tobit estimation results of holding BG companies. In Models 1 and 2, the total wedge $(\mathrm{C} / \mathrm{O})$ and the pyramid wedge $(\mathrm{C} / \mathrm{V})$ have negative and statistically significant coefficients. The controlling families pay out less as these two wedges increase in holding BG companies supporting the rent extraction hypothesis. The coefficients of the dual share wedge $(\mathrm{V} / \mathrm{O})$ are statistically insignificant in Models 3 and 4. These findings support the negative interaction effects of $\mathrm{C} / \mathrm{O}$ and $\mathrm{C} / \mathrm{V}$ in Table 3. Similarly, there is no dual share wedge effect as it is found in Table 3. The FDUMMY is positive and significant in Models 2 and 4. These estimation results show some evidence for the positive influence of controlling foreign-family coalitions on dividend payouts in holding BG companies. Like the findings in other studies (e.g., Bena \& Hanousek, 2008; Baba, 2009; Mian \& Nagata, 2015), large foreign shareholders tend to closely monitor companies and prefer to receive dividend income from their investments.

\footnotetext{
6 When we conduct the same analysis using Dividends/Total assets as the dependent variable, we find that the directions of relationships between Dividends/Total assets and independent variables are consistent with the results in Table 3.
} 
Table 4. CEMs and dividend payouts in family controlled holding BG companies (source: authors' calculations)

\begin{tabular}{|c|c|c|c|c|c|c|}
\hline & & & & \\
\hline & & & Model 1 & Model 2 & Model 3 & Model 4 \\
\hline & & & $\begin{array}{l}\text { Total } \\
\text { Wedge }\end{array}$ & Pyramid Wedge & $\begin{array}{l}\text { Dual-class } \\
\text { Wedge }\end{array}$ & $\begin{array}{l}\text { Pyramid \& } \\
\text { Dual-class } \\
\text { Wedge }\end{array}$ \\
\hline \multirow{6}{*}{ 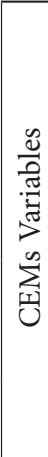 } & Total Wedge & $\mathrm{C} / \mathrm{O}$ & $-0.165^{* *}(-2.16)$ & & & \\
\hline & \begin{tabular}{|l|} 
Pyramid \\
Wedge
\end{tabular} & $\mathrm{C} / \mathrm{V}$ & & $\begin{array}{l}-0.173^{* *} \\
(-2.16)\end{array}$ & & $\begin{array}{c}-0.172 \\
(1.19)\end{array}$ \\
\hline & $\begin{array}{l}\text { Dual Share } \\
\text { Wedge }\end{array}$ & $\mathrm{V} / \mathrm{O}$ & & & $\begin{array}{l}0.137 \\
(0.32)\end{array}$ & $\begin{array}{l}0.090 \\
(0.21)\end{array}$ \\
\hline & Board Size & NB & $0.265^{* * *}(3.39)$ & $0.267^{* * *}(3.44)$ & $0.260^{* * *}(3.31)$ & $0.270^{* * *}(3.44)$ \\
\hline & $\begin{array}{l}\text { Family } \\
\text { Members in } \\
\text { Board }\end{array}$ & FB & $\begin{array}{l}-0.142 \\
(-1.46)\end{array}$ & $\begin{array}{c}-0.149 \\
(1.54)\end{array}$ & $\begin{array}{l}-0.010 \\
(-1.04)\end{array}$ & $\begin{array}{l}-0.152 \\
(-1.55)\end{array}$ \\
\hline & \begin{tabular}{|l} 
Foreign \\
Dummy
\end{tabular} & FDUMMY & $\begin{array}{l}0.075 \\
(1.56) \\
\end{array}$ & $\begin{array}{l}0.079^{*} \\
(1.64) \\
\end{array}$ & $\begin{array}{l}0.063 \\
(1.29) \\
\end{array}$ & $\begin{array}{l}0.081^{*} \\
(1.66)\end{array}$ \\
\hline \multirow{7}{*}{ 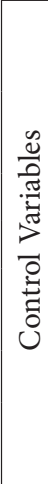 } & Age & AGE & $\begin{array}{l}-0.080 \\
(-0.97)\end{array}$ & $\begin{array}{l}-0.763 \\
(-0.94)\end{array}$ & $\begin{array}{l}-0.031 \\
(-0.39)\end{array}$ & $\begin{array}{l}-0.074 \\
(-0.90)\end{array}$ \\
\hline & Leverage & LEVER & $\begin{array}{c}-0.478^{* * *} \\
(-3.81)\end{array}$ & $\begin{array}{c}-0.476^{* * *} \\
(-3.81)\end{array}$ & $\begin{array}{c}-0.454^{* * *} \\
(-3.63)\end{array}$ & $\begin{array}{c}-0.475^{* * *} \\
(-3.80)\end{array}$ \\
\hline & Profitability & $\mathrm{ROA}$ & $0.661^{* * *}(3.05)$ & $0.664^{* * *}(3.07)$ & $0.685^{* * *}(3.19)$ & $0.666^{* *}(3.08)$ \\
\hline & Size & SIZE & $0.055^{* * *}(2.64)$ & $0.055^{* * *}(2.65)$ & $0.060^{* * *}(2.86)$ & $0.055^{* * *}(2.65)$ \\
\hline & $\begin{array}{l}\text { Growth Op- } \\
\text { portunities }\end{array}$ & GR & $0.000(0.06)$ & $0.001(0.12)$ & $0.001(0.10)$ & $0.001(0.15)$ \\
\hline & Year Effect & & Yes & Yes & Yes & Yes \\
\hline & $\begin{array}{l}\text { Industry } \\
\text { Effect }\end{array}$ & & Yes & Yes & Yes & Yes \\
\hline \multicolumn{3}{|c|}{ Number of observations } & 599 & 599 & 599 & 599 \\
\hline \multicolumn{3}{|c|}{ Left censored observations } & 330 & 330 & 330 & 330 \\
\hline \multicolumn{3}{|c|}{ Wald chi ${ }^{2}$} & $95.25^{* * *}$ & $96.07^{* * *}$ & $90.48^{* * *}$ & $96.47^{* \star *}$ \\
\hline \multicolumn{3}{|c|}{ Likelihood-ratio } & $123.23^{* * *}$ & $119.04^{* * *}$ & $123.48^{* * \star}$ & $111.11^{* * *}$ \\
\hline
\end{tabular}

Notes: Regression coefficients represent the marginal effects on the latent variable $y . \mathrm{z}$ statistics are in parentheses. ${ }^{* * *} \mathrm{p}<0.01,{ }^{* *} \mathrm{p}<0.05,{ }^{*} \mathrm{p}<0.1$.

In Table 5, we show the results of random effects Tobit estimations for non-holding BG companies. Like our findings in Table 3, total wedge $(\mathrm{C} / \mathrm{O})$, pyramid wedge $(\mathrm{C} / \mathrm{V})$ and dual share wedge $(\mathrm{V} / \mathrm{O})$ are statistically insignificant and do not affect the dividend payouts of non-holding BG companies. Unlike the positive and significant foreign dummy variable for holding BG companies, this variable is insignificant for non-holding BG companies. In Tables 4 and 5, except for the statistically insignificant profitability (ROA) variable for nonholding BG companies, the statistical significance results and signs for LEVER and SIZE control variables in the two subsamples are consistent with the results in Table 3 for the whole sample. 
Table 5. CEMs and dividend payouts in family controlled non-holding BG companies (source: authors' calculations)

\begin{tabular}{|c|c|c|c|c|c|c|}
\hline & \multirow{3}{*}{$\begin{array}{c}\text { Model } 1 \\
\text { Total } \\
\text { Wedge }\end{array}$} & \multirow{3}{*}{$\begin{array}{l}\text { Model } 2 \\
\text { Pyramid } \\
\text { Wedge }\end{array}$} & \multirow{3}{*}{$\begin{array}{c}\text { Model } 3 \\
\begin{array}{c}\text { Dual-class } \\
\text { Wedge }\end{array}\end{array}$} & \multirow{3}{*}{$\begin{array}{c}\text { Model } 4 \\
\begin{array}{c}\text { Pyramid \& Du- } \\
\text { al-class Wedge }\end{array}\end{array}$} \\
\hline & & & & & & \\
\hline & & & & & & \\
\hline \multirow{6}{*}{ 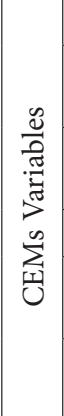 } & Total Wedge & $\mathrm{C} / \mathrm{O}$ & $0.022(0.63)$ & & & \\
\hline & $\begin{array}{l}\text { Pyramid } \\
\text { Wedge }\end{array}$ & $\mathrm{C} / \mathrm{V}$ & & $0.027(0.76)$ & & $0.027(0.76)$ \\
\hline & $\begin{array}{l}\text { Dual Share } \\
\text { Wedge }\end{array}$ & $\mathrm{V} / \mathrm{O}$ & & & $0.012(0.07)$ & $0.013(0.08)$ \\
\hline & Board Size & NB & $0.230^{* *}(2.43)$ & $0.234^{* *}(2.47)$ & $0.232^{* *}(2.39)$ & $0.232^{* *}(2.39)$ \\
\hline & $\begin{array}{l}\text { Family Mem- } \\
\text { bers in Board }\end{array}$ & FB & $\begin{array}{l}0.030 \\
(0.23)\end{array}$ & $\begin{array}{l}0.033 \\
(0.26)\end{array}$ & $0.027(0.210)$ & $\begin{array}{l}0.032 \\
(0.24)\end{array}$ \\
\hline & $\begin{array}{l}\text { Foreign } \\
\text { Dummy }\end{array}$ & FDUMMY & $\begin{array}{l}-0.047 \\
(-0.62)\end{array}$ & $-0.048(-0.77)$ & $\begin{array}{l}-0.048 \\
(-0.77)\end{array}$ & $\begin{array}{l}-0.047 \\
(-0.76)\end{array}$ \\
\hline \multirow{7}{*}{ 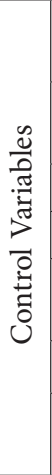 } & Age & AGE & $\begin{array}{l}-0.015 \\
(-0.26)\end{array}$ & $\begin{array}{l}-0.015 \\
(-0.28)\end{array}$ & $\begin{array}{l}-0.172 \\
(-0.30)\end{array}$ & $\begin{array}{l}-0.014 \\
(-0.25)\end{array}$ \\
\hline & Leverage & LEVER & $\begin{array}{c}-0.400^{* * *} \\
(-2.67)\end{array}$ & $\begin{array}{c}-0.398^{* * *} \\
(-2.67)\end{array}$ & $\begin{array}{c}-0.414^{* * *} \\
(-2.79)\end{array}$ & $-0.398^{* * *}(-2.66)$ \\
\hline & Profitability & ROA & $0.396(1.29)$ & $0.400(1.30)$ & $0.380(1.24)$ & $0.400(1.30)$ \\
\hline & Size & SIZE & $0.110^{* * \star}(3.40)$ & $0.109^{* * *}(3.37)$ & $0.112^{* * *}(3.28)$ & $0.110^{* * *}(3.25)$ \\
\hline & $\begin{array}{l}\text { Growth Op- } \\
\text { portunities }\end{array}$ & GR & $\begin{array}{l}0.013 \\
(0.99)\end{array}$ & $0.013(1.00)$ & $0.013(0.99)$ & $0.013(1.00)$ \\
\hline & Year Effect & & Yes & Yes & Yes & Yes \\
\hline & $\begin{array}{l}\text { Industry Ef- } \\
\text { fect }\end{array}$ & & Yes & Yes & Yes & Yes \\
\hline \multicolumn{3}{|c|}{ Number of observations } & 302 & 302 & 302 & 302 \\
\hline \multicolumn{3}{|c|}{ Left censored observations } & 191 & 191 & 191 & 191 \\
\hline \multicolumn{3}{|c|}{ Wald chi $^{2}$} & $46.07^{* * *}$ & $46.61^{* * *}$ & $46.04^{* * *}$ & $46.45^{* * *}$ \\
\hline \multicolumn{3}{|c|}{ Likelihood-ratio } & $43.29^{* * *}$ & $43.26^{* * *}$ & $40.71^{* * *}$ & $40.97^{* * *}$ \\
\hline
\end{tabular}

Notes: regression coefficients represent the marginal effects on the latent variable $y . \mathrm{z}$ statistics are in parentheses, ${ }^{* * *} \mathrm{p}<0.01,{ }^{* *} \mathrm{p}<0.05,{ }^{*} \mathrm{p}<0.1$.

Overall, our estimation results show that as the total wedge and pyramid wedge increase, holding BG companies pay lower dividends supporting the rent extraction hypothesis. For holding BG companies, the effects of financial control variables on dividend payouts are stronger than the effects of CEMs. The effect of board size on dividend payout ratio is positive and significant for both holding and non-holding BG companies. In non-holding BG companies, CEMs do not affect the dividend payouts. The main variables affecting the dividend payouts of non-holding BG companies are the financial control variables. Lastly, we find that having a foreign partner in coalition with a family affects the dividend payouts positively in holding BG companies, and no such effect is found for non-holding BG companies. 


\section{Conclusions}

We examine the impact of CEMs on the dividend payouts of family-controlled holding BG companies compared to those of non-holding BG companies in a low-protection "insider system" setting characterised by majority control similar to privatised companies in Eastern Europe. Our empirical analysis results indicate that different CEMs affect the dividend payouts of holding and non-holding BG companies differently. Specifically, as the divergence between control and ownership rights increases, the rent extraction hypothesis dominates in holding BG companies. In other words, controlling families pay lower dividends to keep resources within the group, and they use the financial holding company to do so. Moreover, in holding BG companies, we find that the dividend payout decreases as the pyramid wedge increases supporting the rent extraction hypothesis. Holding BG companies with coherent pyramid organizational structure under centralized control, have stronger internal capital markets. This structure reduces holding group companies' need for external financing and makes them subject to less outside monitoring by investors and financial institutions. These settings facilitate rent extraction by the controlling family. In addition, our results show that bigger board size curbs the rent extraction in family-controlled holding BG companies by having a positive effect on dividend payout. However, in holding BG companies, the effects of company-specific financial control variables (i.e., leverage, profitability and size) on dividend payouts are stronger. For family controlled non-holding BG companies, the company-specific financial control variables (i.e., leverage and size) are the main determinants of dividend payouts in addition to the positive effect of board size. We could not find any empirical support for the reputation building hypothesis in both holding and non-holding BG companies, and these companies do not use the dividend policy as a mechanism to alleviate the expropriation concerns of minority shareholders.

Our findings have implications such as higher expropriation risk for minority shareholders who invest in family controlled holding BG companies, particularly in a low investor protection setting. For investment decisions in holding BG companies, portfolio managers and investors should consider that a higher level of pyramid wedge is associated with higher expropriation risk. In family controlled holding BG companies, the presence of a controlling foreign and family coalition lowers the possibility of rent extraction. The results show that there is a need for further policy actions to strengthen the rights of minority shareholders to enable them to limit rent extraction by the controlling shareholders. Policy makers can take actions for the development of strong and more transparent financial markets to enhance better monitoring of controlling shareholders. Regulations should be targeted at decreasing the extent of control-enhancing mechanisms. Regulations that reduce the dominance of family members in the board of directors may decrease the extent of expropriations by the controlling family. Moreover, foreign partnerships should be encouraged as a mechanism for enhancing the monitoring. We expect our results to be valid for companies operating in Eastern European markets having similar "crony" capitalism characteristics. Our study can be replicated in these markets for the global validity of our findings.

While the research has several limitations, it also provides directions for future research. First, our sample only covers family controlled BG companies in Turkey and it may not explain the dividend behaviour of all companies with different control structures. This can be a subject for further research. Second, our study covers only non-financial companies and it 
can be replicated for a sample of financial companies to analyse the effect of different CEMs on the dividend behaviour of financial companies. Third, the econometric challenge of finding correct instrumental variables for different types of CEMs still exists in the empirical studies of corporate governance.

\section{Disclosure statement}

The authors have no competing financial, professional, or personal interests from other parties that are related to the subject of this paper.

\section{Acknowledgements}

We thank the participants at the 2017 Multinational Finance Society Conference in Lemesos, Cyprus and at the 2017 International Conference on Banking and Finance Perspectives in Famagusta, North Cyprus for their helpful comments and suggestions.

\section{References}

Adams, R., \& Ferreira, D. (2008). One share-one vote: the empirical evidence. Review of Finance, 12(1), 51-91. https://doi.org/10.1093/rof/rfn003

Adaoglu, C. (2000). Instability in the dividend policy of the Istanbul Stock Exchange (ISE) corporations: evidence from an emerging market. Emerging Markets Review, 1(3), 252-270.

https://doi.org/10.1016/S1566-0141(00)00011-X

Adaoglu, C. (2008). Dividend policy of the ISE industrial corporations: the evidence revisited (19862007). Journal of BRSA Banking and Financial Markets, 2(2), 113-136.

Adjaoud, F., \& Ben-Amar, W. (2010). Corporate governance and dividend policy: shareholders' protection or expropriation? Journal of Business Finance and Accounting, 37(5-6), 648-667. https://doi.org/10.1111/j.1468-5957.2010.02192.x

Aivazian, V., Booth, L., \& Cleary, S. (2003). Do emerging market firms follow different dividend policies from U.S. firms? The Journal of Financial Research, 26(3), 371-387. https://doi.org/10.1111/1475-6803.00064

Almeida, H., Park, S., Subrahmanyam, M., \& Wolfenzon, D. (2007). Beyond cash flow and voting rights: valuation and performance of firms in complex ownership structures. EFA 2008 Athens Meetings Paper. https://doi.org/10.2139/ssrn.1101865

Alzahrani, M., \& Lasfer, M. (2012). Investor protection, taxation, and dividends. Journal of Corporate Finance, 18(4), 745-762. https://doi.org/10.1016/j.jcorpfin.2012.06.003

Amoako-Adu, B., Baulkaran, V., \& Smith, B. F. (2014). Analysis of dividend policy of dual and single class U.S corporations. Journal of Economics and Business, 72, 1-29. https://doi.org/10.1016/j.jeconbus.2013.10.002

Anderson, R. C., \& Reeb, D. M. (2003). Founding-family ownership and firm performance: evidence from the S\&P 500. Journal of Finance, 58(3), 1301-1328. https://doi.org/10.1111/1540-6261.00567

Baba, N. (2009). Increased presence of foreign investors and dividend policy of Japanese firms. PacificBasin Finance Journal, 17(5), 163-174. https://doi.org/10.1016/j.pacfin.2008.04.001

Baker, H. K., Kilincarslan, E., \& Arsal, A. H. (2018). Dividend policy in Turkey: survey evidence from Borsa Istanbul firms. Global Finance Journal, 35, 43-55. https://doi.org/10.1016/j.gf.2017.04.002 
Bena, J., \& Hanousek, J. (2008). Rent extraction by large shareholders: evidence using dividend policy in the Czech Republic. Czech Journal of Economics and Finance, 58(3-4), 106-130.

Benavides, J., Berggrun, L., \& Perafan, H. (2016). Dividend payout policies: evidence from Latin America. Finance Research Letters, 17, 197-210. https://doi.org/10.1016/j.frl.2016.03.012

Bennedsen, M., \& Nielsen, K. M. (2010). Incentive and entrenchment effects in European ownership. Journal of Banking and Finance, 34(9), 2212-2229. https://doi.org/10.1016/j.jbankfin.2010.02.007

Bertrand, M., Mehta, P., \& Mullainathan, S. (2002). Ferreting out tunneling: an application to Indian business groups. Quarterly Journal of Economics, 117(1), 121-148. https://doi.org/10.1162/003355302753399463

Black, F. (1976). The dividend puzzle. Journal of Portfolio Management, 2(2), 5-8. https://doi.org/10.3905/jpm.1976.408558

Botoc, C., \& Pirtea, M. (2014). Dividend payout-policy drivers: evidence from emerging countries. Emerging Markets Finance and Trade, 50(4), 95-112. https://doi.org/10.2753/REE1540-496X5004S407

Bradford, W., Chen, C., \& Zhu, S. (2013). Cash dividend policy, corporate pyramids, and ownership structure: Evidence from China. International Review of Economics \& Finance, 27(C), 445-464. https://doi.org/10.1016/j.iref.2013.01.003

Brennan, M. (1970). Taxes, market valuation and corporate financial policy. National Tax Journal, 23, 417-427.

Brockman, P., \& Unlu, E. (2011). Earned/contributed capital, dividend policy, and disclosure quality: an international study. Journal of Banking and Finance, 35(7), 1610-1625. https://doi.org/10.1016/j.jbankfin.2010.11.014

Bulan, L., \& Hull, T. (2013). The impact of technical defaults on dividend policy. Journal of Banking and Finance, 37(3), 814-823. https://doi.org/10.1016/j.jbankfin.2012.10.014

Byrne, J., \& O'Connor, T. (2012). Creditor rights and the outcome model of dividends. The Quarterly Review of Economics and Finance, 52(2), 227-242. https://doi.org/10.1016/j.qref.2012.04.002

Casado, R. B., Burkert, M., Dávila, A., \& Daniel, O. (2016). Shareholder protection: the role of multiple large shareholders. Corporate Governance: An International Review, 24(2), 105-129. https://doi.org/10.1111/corg.12131

Chen, E. T., \& Nowland, J. (2010). Optimal board monitoring in family owned companies: evidence from Asia. Corporate Governance: An International Review, 18(1), 3-17. https://doi.org/10.1111/j.1467-8683.2009.00778.x

Chen, X., Yong, S., \& Xiaodong, X. (2016). Free cash flow, over-investment and corporate governance in China. Pacific-Basin Finance Journal, 37, 81-103. https://doi.org/10.1016/j.pacfin.2015.06.003

Chen, Z., Cheung, Y. L., Stouraitis, A., \& Wong, A. W. S. (2005). Ownership concentration, firm performance, and dividend policy in Hong Kong. Pacific-Basin Finance Journal, 13, 431-449. https://doi.org/10.1016/j.pacfin.2004.12.001

Coulton, J. J., \& Ruddock, C. (2011). Corporate payout policy in Australia and a test of the life-cycle theory. Accounting and Finance, 51, 381-407. https://doi.org/10.1111/j.1467-629X.2010.00356.x

Dahlquist, M., Robertsson, G., \& Rydqvist, K. (2014). Direct evidence of dividend tax clienteles. Journal of Empirical Finance, 28, 1-12. https://doi.org/10.1016/j.jempfin.2014.05.003

DeAngelo, H., \& DeAngelo, L. (2006). The irrelevance of the MM dividend irrelevance theorem. Journal of Financial Economics, 79, 293-315. https://doi.org/10.1016/j.jfineco.2005.03.003

DeAngelo, H., DeAngelo, L., \& Stulz R. (2006). Dividend policy and the earned/contributed capital mix: a test of the life-cycle theory. Journal of Financial Economics, 81, 227-254. https://doi.org/10.1016/j.jfineco.2005.07.005

De Cesari, A. (2012). Expropriation of minority shareholders and payout policy. The British Accounting Review, 44(4), 207-220. https://doi.org/10.1016/j.bar.2012.09.002 
Demirag, I., \& Serter, M. (2003). Ownership patterns and control in Turkish listed companies. Corporate Governance: An International Review, 11(1), 40-51. https://doi.org/10.1111/1467-8683.00300

Desai, M. A., \& Jin, L. (2011). Institutional tax clienteles and payout policy. Journal of Financial Economics, 100(1), 68-84. https://doi.org/10.1016/j.jfineco.2010.10.013

Easterbrook, F. H. (1984). Two agency-cost explanations of dividends. The American Economic Review, 74(4), 650-659.

Elton, E. J., \& Gruber, M. J. (1970). Marginal stockholder tax rates and the clientele effect, Review of Economics and Statistics, 52(1), 68-74. https://doi.org/10.2307/1927599

Faccio, M., Lang, L. H. P., \& Young, L. (2001). Dividends and expropriation. American Economic Review, 91(1), 54-78. https://doi.org/10.1257/aer.91.1.54

Faccio, M., \& Lang, L. H. P. (2007). The ultimate ownership of western European corporations. In A. I. Ruud, van Frederikslust, J. S. Ang, \& P. S. Sudarsanam, Corporate Governance and Corporate Finance: A European Perspective (pp. 163-190). London: Routledge. https://doi.org/10.4324/9780203940136

Friedman, E., Johnson, S., \& Mitton, T. (2003). Propping and tunneling. Journal of Comparative Economics, 31(4), 732-750. https://doi.org/10.1016/j.jce.2003.08.004

González, M., Guzmán, A., Pombo, C., \& Trujillo, M. A. (2014). Family involvement and dividend policy in closely held firms. Family Business Review, 27(4), 365-385.

https://doi.org/10.1177/0894486514538448

González, M., Molina C. A., Pablo, E., \& Rosso J. W. (2017). The effect of ownership concentration and composition on dividends: evidence from Latin America. Emerging Markets Review, 30, 1-18. https://doi.org/10.1016/j.ememar.2016.08.018

Gordon, M. J. (1963). Optimal investment and financing policy. Journal of Finance, 18, 264-272.

Grullon, G., Michaely, R., \& Swaminathan, B. (2002). Are dividend changes a sign of firm maturity. Journal of Business, 75(3), 387-424. https://doi.org/10.1086/339889

Gugler, K., \& Yurtoglu, B. B. (2003). Corporate governance and dividend payout policy in Germany. European Economic Review, 47(4), 731-758.

Harada, K., \& Nguyen, P. (2011). Ownership concentration and dividend policy in Japan. Managerial Finance, 37(4), 362-379. https://doi.org/10.1108/03074351111115313

Isakov, D., \& Weisskopf, J. P. (2015). Pay-Out policies in founding family firms. Journal of Corporate Finance, 33(C), 330-344. https://doi.org/10.1016/j.jcorpfin.2015.01.003

Iturriaga, F. L., \& Crisóstomo, V. L. (2010). Do leverage, dividend payout, and ownership concentration influence firms' value creation? An analysis of Brazilian firms. Emerging Markets Finance and Trade, 46(3), 80-94. https://doi.org/10.2753/REE1540-496X460306

Jacob, M., \& Michaely, R. (2017). Taxation and dividend policy: the muting effect of agency issues and shareholder conflicts. Review of Financial Studies, Forthcoming. https://doi.org/10.1093/rfs/hhx041

Jensen, M. C., \& Meckling, W. H. (1976). Theory of the firm: managerial behavior, agency costs and ownership structure. Journal of Financial Economics, 3(4), 305-360. https://doi.org/10.1016/0304-405X(76)90026-X

Jensen, M. C. (1986). Agency costs of free cash flow, corporate finance, and takeover. American Economic Review, 76, 323-329.

Jiraporn, P., \& Ning, Y. (2006). Dividend policy, shareholder rights, and corporate governance. Journal of Applied Finance, 16(2), 24-36. https://doi.org/10.2139/ssrn.931290

Johnson, S., La Porta, R., Lopez-De-Silanes, F., \& Shleifer, A. (2000). Tunnelling. American Economic Review, 90(2), 22-27. https://doi.org/10.1257/aer.90.2.22

Karpavičius, S., \& Yu, F. (2017). How institutional monitoring creates value: evidence for the free cash flow hypothesis. International Review of Economics \& Finance, 52, 127-146.

https://doi.org/10.1016/j.iref.2017.10.016 
Khanna, T., \& Yafeh, Y. (2010). Business groups in emerging markets: paragons or parasites? In The Oxford Handbook of Business Groups. https://doi.org/10.1093/oxfordhb/9780199552863.003.0020

Kuo, L. (2017). Reputation as a governance mechanism? Evidence from payout policy of insider-controlled firms in Taiwan. Journal of Business Finance \& Accounting, 44(9-19), 1443-1476. https://doi.org/10.1111/jbfa.12261

La Porta, R., Lopez-de-Silanes, F., \& Shleifer, A. (1999). Corporate ownership around the world. Journal of Finance, 54(2), 471-517. https://doi.org/10.1111/0022-1082.00115

La Porta, R., Lopez-De-Silanes, F., Shleifer, A., \& Vishny, R. W. (2000). Agency problems and dividend policies around the world. Journal of Finance, 55(1), 1-33. https://doi.org/10.1111/0022-1082.00199

Lins, K. V. (2003). Equity ownership and firm value in emerging markets. The Journal of Financial and Quantitative Analysis, 38(1), 159-184. https://doi.org/10.2307/4126768

Lintner, J. (1956). American economic association distribution of incomes of corporations among dividends, retained earnings, and taxes. The American Economic Review, 46(2), 97-113.

Lintner, J. (1962). Dividends, earnings, leverage, stock prices and supply of capital to corporations. The Review of Economics and Statistics, 64, 243-269. https://doi.org/10.2307/1926397

Litzenberger, R. H., \& Ramaswamy, K. (1979). The effects of personal taxes and dividends on capital asset prices: Theory and empirical evidence. Journal of Financial Economics, 7, 163-195. https://doi.org/10.1016/0304-405X(79)90012-6

Liu, M., \& Magnan, M. (2011). Self-dealing regulations, ownership wedge, and corporate valuation: international evidence. Corporate Governance, 19(2), 99-115. https://doi.org/10.1111/j.1467-8683.2010.00839.x

Mancinelli, L., \& Ozkan, A. (2006). Ownership structure and dividend policy: evidence from Italian firms. The European Journal of Finance, 12(3), 265-282. https://doi.org/10.1080/13518470500249365

Masulis, R. W., Wang, C., \& Xie, F. (2009). Agency problems at dual-class companies. Journal of Finance, 64(4), 1697-1727. https://doi.org/10.1111/j.1540-6261.2009.01477.x

Mian, R., \& Nagata, K. (2015). Foreign institutional ownership and the valuation effect of investment and payout decisions. Journal of Finance and Economics, 3(5), 97-104. https://doi.org/10.12691/jfe-3-5-3

Miller, M., \& Modigliani, F. (1961). Dividend policy, growth, and the valuation of shares. The Journal of Business, 34(4), 411-433. https://doi.org/10.1086/294442

Mitton, T. (2004). Corporate governance and dividend policy in emerging markets. Emerging Markets Review, 5(4), 409-426. https://doi.org/10.1016/j.ememar.2004.05.003

Moortgat, L., Annaert, J., \& Deloof, M. (2017). Investor protection, taxation and dividend policy: longrun evidence, 1838-2012. Journal of Banking \& Finance, 85, 113-131. https://doi.org/10.1016/j.jbankfin.2017.08.013

Pindado, J., Requejo, I., \& Torre, C. (2012). Do family firms use dividend policy as a governance mechanism? Evidence from the Euro zone. Corporate Governance: An International Review, 20(5), 413-431. https://doi.org/10.1111/j.1467-8683.2012.00921.x

Pirgaip, B., \& Karacaer, S. (2015). Short-term price effects of stock repurchases in Turkish capital markets. International Journal of Economics and Finance, 7(12), 29-43.

https://doi.org/10.2139/ssrn.2650418

Sacristán- Navarro, M., Gómez-Anson, S. \& Cabeza, L. (2011). Large shareholder's combinations in family firms: prevalence and performance effects. Journal of Family Business Strategy, 2(2), 101-112. https://doi.org/10.1016/j.jfbs.2011.03.001

Setia-Atmaja, L., George A. T., \& Skully, M. (2009). The role of dividends, debt and board structure in the governance of family controlled firms. Journal of Business Finance and Accounting, 36(7-8), 863-898. https://doi.org/10.1111/j.1468-5957.2009.02151.x

Setia-Atmaja, L. (2016). The impact of family control on dividend policy: Evidence from Indonesia. The International Research Journal of Business Studies, 9(3), 147-156.

https://doi.org/10.21632/irjbs.9.3.147-156 
Shleifer, A., \& Vishny, R. W. (1997). A survey of corporate governance. The Journal of Finance, 52(2), 737-783. https://doi.org/10.1111/j.1540-6261.1997.tb04820.x

Thanatawee, Y. (2011). Life-cycle theory and free cash flow hypothesis: evidence from dividend policy in Thailand. International Journal of Financial Research, 2(2). https://doi.org/10.5430/ijfr.v2n2p52

Tran, Q. T., Alphonse, P., \& Nguyen, X. M. (2017). Dividend policy: shareholder rights and creditor rights under the impact of the global financial crisis. Economic Modelling, 64, 502-512. https://doi.org/10.1016/j.econmod.2017.03.010

Tvaronavičiene, M., \& Kalašinskaite, K. (2005). Analysis of privatization: different approaches. Journal of Business Economics and Management, 6(1), 53-59.

Villalonga, B., \& Amit, R. (2006). How do family ownership, control, and management affect firm value? Journal of Financial Economics, 80(2), 385-417. https://doi.org/10.1016/j.jineco.2004.12.005

Villalonga, B., \& Amit, R. (2009). How are U.S. family firms controlled? Review of Financial Studies, 22(8), 3047-3091. https://doi.org/10.1093/rfs/hhn080

World Economic Forum. (2017). The Global Competitiveness Report 2017-2018. World Economic Forum Reports 2017.

Yurtoglu, B. B. (2000). Ownership, control and performance of Turkish listed firms. Empirica, 27(2), 193-222. https://doi.org/10.1023/A:1026557203261

Yurtoglu, B. B. (2003). Corporate governance and implications for minority shareholders in Turkey. Corporate Ownership and Control, 1(1), 72-86. https://doi.org/10.22495/cocvlilp9

\section{APPENDIX}

Description of variables

\begin{tabular}{|l|l|}
\hline \multicolumn{2}{|l|}{ Dependent variable } \\
\hline DIV/EARN & $\begin{array}{l}\text { Dividends are cash dividends paid to shareholders. Earnings are measured after taxes } \\
\text { and interest but before extraordinary items }\end{array}$ \\
\hline CEM explanatory variables \\
\hline C/O & The ratio of control rights to ownership rights owned by the controlling family \\
\hline C/V & Pyramid wedge (additional control via pyramids) \\
\hline V/O & Dual share wedge (additional control via dual class stock) \\
\hline HOL & $\begin{array}{l}\text { Holding dummy variable }=1 \text { If the company is controlled via a holding intermedi- } \\
\text { ary company, otherwise } 0\end{array}$ \\
\hline NB & Board size calculated as natural logarithm of number of board members \\
\hline FB & $\begin{array}{l}\text { Ratio of family members in board, calculated as the ratio of number of family mem- } \\
\text { bers in the board to number of board members }\end{array}$ \\
\hline FDUMMY & $\begin{array}{l}\text { Dummy variable }=1 \text { if the company is controlled together with a foreign entity, oth- } \\
\text { erwise } 0\end{array}$ \\
\hline Control variables \\
\hline AGE & Natural logarithm of number of years since incorporation \\
\hline LEVER & Leverage calculated as total debt divided by total assets \\
\hline ROA & Return on assets calculated as net income divided by total assets \\
\hline SIZE & Natural logarithm of total assets \\
\hline GR & Growth opportunities calculated as market to book ratio \\
\hline
\end{tabular}

